\title{
KRIKŠČIONIŠKOJO DVASINIO AUGIMO SAMPRATA IR RAIDOS BRUOŽAI
}

\author{
Albinas Šiaudvytis, Vaineta Juškienè \\ Klaipèdos universitetas
}

\begin{abstract}
Anotacija
Straipsnyje analizuojamas dvasinio augimo procesas, kaip kiekvieno krikščionio gyvenimo integralus sandas. Aptariamas šio fenomeno terminijos ir teoriju spektras, detalizuojama dvasinio augimo dinamika, struktūra bei etapai. Aktualizuojama dvasinio augimo reikšmè Šventojo Rašto bei Bažnyčios Magisteriumo požiūriais, kur šis procesas atsiskleidžia kaip visuotinis Bažnyčios ir kiekvieno jos nario pašaukimas. Svarstomos teologijos ir psichologijos tarpusavio ryšio galimybès, galinčios padèti išlaikyti holistini požiūrị ị asmens augimą bei jo santykị su Dievu.

PAGRINDINIAI ŽODŽIAI: dvasinis augimas, šventumas, krikščioniška branda.
\end{abstract}

\begin{abstract}
The analysis of the article focuses on the process of spiritual growth as integral component of every Christian life. The terminological and theoretical spectrum of this phenomenon is discussed together with elaboration of the dynamics, structure, and stages of spiritual growth. The significance of spiritual growth from the biblical and Church Magisterium perspectives is actualized. From these perspectives the process of spiritual growth is seen as a universal calling of the Church and its members. The possible linkages between theology and psychology are discussed as ways which can help to retain the holistic approach to the personal growth and one's relationship with God.
\end{abstract}

KEY WORDS: spiritual growth, holiness, christian maturity.

\section{Ivadas}

Nesuklysime teigdami, kad pagrindinis krikščioniško gyvenimo principas ir tikslas - nuolatinis panašumo su Kristumi siekimas, besitęsiantis visą gyvenimą, apimantis mąstymą, santykius su žmonėmis ir pasauliu. Būtinybẻ augti yra kiekvieno žmogaus gyvenimo pašaukimas (plg. Vanier, 1994). Psichiatras M. Scott'as Peck'as (2012, p. 52) teigia, ,žmogaus egzistencijos tikslas yra dvasinis tobulejjimas“. Dvasinis augimas pagrịstas paties Dievo rūpesčiu, kai sukurdamas žmogų ,pagal savo paveikslą ir panašumą““ $(\operatorname{Pr} 1$, 
27) Jis panorejjo jo kaip pašnekovo, bičiulio ir leido jam tapti tinkamu dialogo partneriu. Tiek Senosios Sandoros tautos žmonès, tiek Bažnyčios nariai kviečiami augti, šventèti - savo gyvenimu siekti tikros bičiulystès su Dievu. Jèzus ne tik ragino savo sekejjus šventèti, bet ir savo gyvenimu rodẻ dvasinio augimo pavyzdị. Per Šventają Dvasią Dievas nuolat skatina žmones trokšti tobulèti ir padeda tai ịgyvendinti teikdamas malones bei dovanas. Apaštalas Paulius dvasini augimą nusako kaip supanašèjimą su Jėzumi - ne vien išoriškai, bet ir jame ịsišaknijant bei ịsitvirtinant (plg. Ef 3, 17), susitapatinant su Juo, kad galima būtų ištarti: „Aš gyvenu, tačiau nebe aš, o manyje gyvena Kristus“ (Gal 2, 20). Biblinis požiūris nurodo krikščioniškojo tikejjimo ir gyvenimo dinamiką, kur dvasinio gyvenimo patirtis bei apraiškos gali augti ir keistis (plg. 2 Pt 3, 18; 1 Pt 2, 1-2). Tačiau krikščionys, sekdami Jėzumi, dažnai išgyvena įtampą ir patiria sunkumų, kai jų tikèjimo augimas susiduria su gyvenimo tikrove. Tie iššūkiai liudija analizuojamos temos aktualumą ir skatina ieškoti naujų į̌̌valgų. Šiame kontekste svarbu aptarti krikščioniško pašaukimo augti fenomeną, susipažinti su ji nusakančiomis teorijomis, struktūra ir etapais, suvokti galimas įtampas tarp teologijos ir psichologijos tyrinejjant ši reiškinị. Nemažiau svarbu atskleisti ir pagrindines krikščioniškas prielaidas, lemiančias tikrą dvasinị augimą. Atsižvelgiant ị šias realijas, šiame straipsnyje keliamas tiks las - aptarti krikščioniškojo dvasinio augimo sampratą ir prielaidas dabarties aktualijų kontekste.

Tyrimo metodai: literatūros analizè, sisteminimas, interpretacija.

Tyrimas paremtas humanistine nuostata, pabrèžiančia dvasinị asmens pradą ir laikančia ji esminiu ịgimtu žmogaus ugdymosi pamatu. Remiantis šiuo požiūriu, žmogus nuolat yra tapsmo procese. Krikščioniškas dvasinis augimas yra integrali minèto tapsmo dalis.

\section{Krikščioniško dvasinio augimo terminologija}

Tikintis žmogus yra pašauktas ị dieviškają palaimą, kurios privalo siekti laisvai, sąmoningai ir ugdydamasis veikiant Dievo malonei (plg. KBK, nr. 1700). Tad krikščionio gyvenimas yra neatsiejamas nuo šventumo, tobulèjimo ir augimo. Tikejjimu susietas su Kristumi ir Jo išganymo darbu tikintysis 
yra veikiamas ,šlovingo ir dvasinio Jėzaus Kristaus asmens per objektyvų buvimo santykị, kuris žmogų daro „nauju kūriniu“ (plg. 2 Kor 5, 17; Nuovo dizionario di teologia, 1988, p. 420). Šis tikinčiojo gyvenimo ịsipareigojimas išlieka nuolatiniu dvasinio augimo svarstymų objektu. Tikejjimo paieškos ir bandymai aprašyti dvasinị augimą teologineje ar sekuliarioje literatūroje ịvardijami įvairiais terminais.

Krikščioniškam dvasiniam augimui aptarti dažnai vartojamos religingumo, dvasingumo, šventumo, pamaldumo, askezès, dvasinio tobulejimo, dvasinio gyvenimo, dvasinio augimo, Jèzaus sekimo sąvokos. Religingumo terminas yra bendresnio pobūdžio ir apima išorines tikèjimo apraiškas bei tendencijas, dažnai būdingas kiekvienos religijos tikrovei. Tam tikrų krikščioniškų bažnyčių tradicijoje jis turi neigiamą atspalvị, pabrèžiant išskirtinị, klaidingą tikinčiojo angažavimąsi ị išorines tikèjimo praktikavimo formas, kai žmogus tikejjimo iš esmès nepaveikiamas ir jo gyvenimas Dievo iš vidaus neperkeičiamas - nèra asmeniškumo, kryptingumo ir realizacijos Dievo asmens link (plg. Kavaliauskas, 1992). Pamaldumas yra anksčiau vartota sąvoka, kurios moderniais laikais neretai atsisakoma. Ji apsiriboja plačiau aptariamomis įvairiomis maldos praktikomis. Askezė apima krikščionio pastangas sekti Jėzumi kovojant su nuodème, mokantis dorybių, atsižadant savęs ir visą gyvenimą „mokantis mirti“ dèl atsidavimo Dievui (plg. Vorgrimler, 2003). Neretai krikščioniškajai askezès sampratai buvo būdingi tam tikri iškraipymai: pasaulio niekinimas, nusigręžimas nuo atsakomybės už kūriniją, kūrinijos dovanų niekinimas, kurie šiandienos žmogui atrodo pernelyg radikalūs ir nuo gyvenimo tikrovès nutolę dalykai (plg. Vorgrimler, 2003). Dvasinis tobulejjimas, dvasinis gyvenimas, dvasinis augimas, Jèzaus sekimas apima aktyvias krikščionio pastangas pažinti Dievą, formuoti elgseną pagal Jėzaus pavyzdị ir savo gyvenime aktualizuoti tikèjimą. Neretai dabarties dvasinejje literatūroje šios sąvokos vartojamos kaip sinonimai. Straipsnyje nesiimta gilintis ị minètų sąvokų diferenciaciją, jos bus aptariamos apibendrintai krikščioniško dvasinio augimo perspektyvoje.

Dar viena iš dažniausiai aptinkamų sąvokų dvasinio augimo procese šventumas. Kartais ji vartojama krikščioniško dvasinio augimo aptartyse kaip pastarojo tikslas. Krikščionybès istorijoje ir Tradicijoje šventumas laikomas 
būtina tikinčio žmogaus elgsenos kryptimi. Kvietimas šventėti aptinkamas Biblijoje nuo pirmujų jos puslapių: „Eik mano keliu ir būk be priekaišto“ (Pr 17, 1), galiausiai yra Jėzaus pakartotas: „Būkite tokie tobuli, kaip jūsų dangiškasis Tèvas yra tobulas“ (Mt 5, 48). Šventumas, kaip tikinčio žmogaus pastanga atkurti savyje esanti „Dievo paveikslą ir panašumą“ $(\operatorname{Pr} 2,7)$ ir veržimasis ị galutinę vienybę su Dievu, geriausiai nusako krikščionio dvasinio augimo tikslą, motyvaciją, dinamiką. Tačiau neretai istorijoje ši sąvoka vartota perdèm rezervuotai. Pašaukimą šventèti Bažnyčioje reabilitavo Vatikano II Susirinkimas, kuris aiškiai ir nevienareikšmiškai pabrèžè, kad tai visuotinis Bažnyčios ir kiekvieno jos nario pašaukimas: „Visi Kristaus tikintieji, kad ir kokia būtų jų padetis ir luomas, Viešpaties pašaukiami kiekvienas savo keliu siekti tobulybės to šventumo, kuriuo tobulas yra pats Tẻvas“ (LG, nr. 11). Šventumo visuotinumą dar kartą aktualizavo Šventasis Tẻvas Pranciškus Apaštališkuoju paraginimu Gaudete et Exsultate apie pašaukimą i šventumą šiuolaikiniame pasaulyje (Šventasis Tẻvas Pranciškus, 2018). Šventumas, kaip skelbia popiežius Pranciškus, iš krikščionių ,reikalauja visko ir už tai siūlo tikrajị gyvenimą, laimę, kuriai esame sukurti“ (GE, nr. 1). Taigi dar Vatikano II Susirinkimo mokymo paskatintas Bažnyčios atsinaujinimas šiuo aspektu sukèlè „,visuotinị dèmesio dvasingumui atgimimą ir daugelio naujų tarnybos formų proveržị “ (Hart, 2001, p. 38), kurios ypač palaikomos dabarties Bažnyčios dokumentuose ir praktikoje. Tad galima teigti, kad šventumo terminas yra dvasinio augimo pamatas, nurodantis tikinčiojo atsidavimo Dievui užduotis savo tikejjimu ir gyvenimu vykdyti Jo paliepimus.

Terminų ịvairovė krikščioniškojoje literatūroje atskleidžia dvasinio augimo fenomeno gylị. Tai sudėtingas procesas, kuris remiasi Dievo ir žmogaus abipusių santykių ịtvirtinimu ir puoselejjimu, tai atskleidžiama krikščionių autorių literatūroje.

\section{Krikščioniško dvasinio augimo aptartys}

Dvasinio augimo fenomenas krikščioniškaji dvasingumą analizuojančių autorių vienareikšmiškai neapibrèžtas. Teologas Ralph'as Martin'as (2017) šiuo požiūriu neskiria minèto šventumo siekimo ir dvasinio augimo proceso, 
juos laiko ta pačia dvasine kelione, siekiant vienybès su Dievu. Dvasingumo tyrinètojas ir teologas Marco Ivan'as Rupnik'as (1997) dvasinị gyvenimą apibrež̌ia kaip meną, kuris bendradarbiaujant su Šventaja Dvasia daro vaisingą Dievo buvimą krikščionio gyvenime. Valerio Albisetti (2001) dvasinị augimą pristato kaip kelionę, prasidedančią nuo savęs peržengimo ir spirale, kurios ašimi yra Dievas, judančią kartu su Juo bei kitais žmonėmis. Benedict'as J. Groeschel'is (2014) dvasini gyvenimą apibrèžia kaip visumą to, kaip žmogus atsiliepia ị vidinị Dievo kvietimą. Teologas Tadeusz'as Dajcze (2010) dvasinį augimą pristato kaip tikinčio žmogaus savirealizaciją Kristuje. Psichoanalitikas Carl'as Frielingsdorf'as (2003) jị apibrěžia kaip krikščionio asmenybès realizavimąsi ir visapusišką išganymo siekimą. John'as Stott'as (2004) dvasini gyvenimą vadina visapusišku žmogaus gyvenimu, gyvenamu Dievo valdžioje. Filosofas teologas Luigi Giussan (2007) jị ịvardija kaip visapusišką žmogaus asmenybès realizavimąsi, o naujųų evangelikų teologas Peter Scazzero (2010, p. 24) bando susieti psichologijos bei klasikinès teologijos patirtis ir dvasini gyvenimą laiko emocinès bei krikščionio dvasinès brandos siekiu asmeninejje kelionèje su Kristumi. Trapistų vienuolis ir dvasinis rašytojas Thomas Merton'as (1997) apie dvasini augimą kalba kaip apie visapusišką Kristaus pasireiškimą krikščionio gyvenime, panašiai ir Henry Cloud'as bei John'as Townsend'as (2003) jị apibūdina kaip sugrịžimą i pilnutini gyvenimą, kurị tikintiesiems numatè Dievas. Ronald'as Rolheiser'is (2017, p. 25) skiria keletą svarbių dvasinio augimo elementų: „Gebejjimas, apimantis discipliną ir ịpročius, kurie pasitarnauja didesnei mūsų kūno ir sielos integracijai, labiau suartina mus su Dievu, žmonèmis ir pasauliu. "Bažnyčios Magisteriumas (KBK, nr. 1700-2557) dvasinị augimą ịvardija kaip „žmogaus krikščionio pašaukimą gyventi Šventojoje Dvasioje ir to pašaukimo realizacijos ịgyvendinimą konkrečiose gyvenimo situacijose“. Popiežius Paulius VI suaugusiųų katekizme (Catechismo degli adulti, 1995, p. 400) pabrèžia ,asmens pašaukimą ị bendrystę su Tèvu, Sūnumi ir Šventaja Dvasia, asmens būties ir jo veiksmų atnaujinimą, asmens laisvą apsisprendimą augti meilès pilnatvejje“. Naujasis teologijos žodynas (Vorglimrer, 2003) akcentuoja santykį su Dievu ir sąmoningą subjektyvią laikyseną žmoguje esančios Šventosios Dvasios atžvilgiu bei ị artimą orientuotą tikèjimo praktiką. Bandydami 
apibrezžti integralų krikščionio dvasinị augimą, galime ịžvelgti jo tęstinumą: Šventosios Dvasios palaikomas krikščionis pradeda sunkią kelionę, kuri iš nuodėmès veda ị šventumą; pasitikẻdamas Dievo gailestingumu, apreikštu Jèzaus Kristaus, jis prisipažįsta esąs nusidejjèlis, atsiverčia ir melsdamasis, priimdamas sakramentus, apsivalydamas ir nusiskaistindamas, tarnaudamas kitiems ir ugdydamas dorybes stengiasi augti ir tobulèti mokydamasis mylèti (plg. Catechismo degli adulti, 1995, p. 452; KBK, nr. 1846-1876).

Galima teigti, kad dvasinio augimo procesas apima visą žmogų ir ši kelionè tęsiasi visą jo gyvenimą. Jis apima kasdieniškas tikinčio žmogaus pastangas sekti Jėzumi konkrečiose gyvenimo ir tarnystės situacijose. Apibendrinant dvasinio augimo aptarimą pastebimi keli būdingi pasikartojantys elementai, nusakantys reiškinio esmę. Šis procesas yra dinamiškas - kelionè, sugrị̌imas, siekimas, suartejjimas. Jo centre - santykis su Dievu, neišskiriant nè vieno Trejybès asmens. Proceso tikslas - visiškas žmogiškojo asmens išsiskleidimas ir savirealizacija.

\section{Krikščioniškojo dvasinio augimo dinamika}

Dvasinis augimas - tai būdas ịgyvendinti Dievo planą, būti kartu su Juo visą amžinybę. Jo šaknys glūdi Šventajame Rašte, Tradicijoje ir Bažnyčios mokyme. Iš aptartų apibrèžimų ryškejja bendri dvasinio augimo principai: Šventosios Dvasios veikimas, savęs peržengimas, Bažnyčios, kaip bendruomenès, svarba, kristocentriškumas, Dievo pirmapradès tvarkos atkūrimas kūrinijoje ir žmoguje. Minètos aptartys leidžia išvysti paties reiškinio dinamiką, kuri atsiskleidžia tikejjime kaip kelionèje, siekiuose, mene, gyvenime, santykyje - ịvairiuose procesuose. Tai atskleidžia krikščioniškojo tikejjimo ir gyvenimo vystymosi, keitimosi tendencijas. Dvasine patirtis ir dvasinio gyvenimo apraiškos gali keistis, tad krikščionio pareiga tuos pokyčius skatinti (plg. 2 Pt 3, 18; 1 Pt 2, 1-2).

Be tradicinès teologinès dvasinio augimo prieigos, besiremiančios Šventuoju Raštu, Bažnyčios mokymu ir Tradicija, teologai ir psichologai diskutuoja apie krikščionio brandumą, jị nusakančius bruožus bei įtaką dariusius veiksnius. J. Catalan'as (2003, p. 10) kelia klausimą, ar „egzistuoja ryšys 
tarp sveikos žmogiškosios pusiausvyros ir to, kas vadinama dvasiniu brandumu?“ B. J. Groeschel'io (2014, p. 63) teigimu, „kad suprastume dvasini augimą, yra labai svarbu suvokti gyvos būtybès raidos prigimtị “. Aptardami krikščionio dvasinę brandą, kai kurie autoriai renkasi psichoanalitiko Eriko H. Erikson'o siūlomą aštuonių žmogaus raidos etapų teoriją, kuri teigia, kad tam tikrais kritiškais žmogaus gyvenimo ciklo laikotarpiais individo psichikoje išnyra nauji dalykai - vertybès, ịgūdžiai: pasitikejjimo jausmas, savarankiškumo siekis ir savigarba, iniciatyvumas, darbštumas, tapatybė, artimumas, kūrimas, ego vientisumas (plg. Erikson, 2004). Kai kurių autorių (Groeschel, 2014; Paškus, 1990) teigimu, tai leidžia stebèti psichinès ir religinès raidos sąlyti psichologinès brandos procese. A. Paškus lygiagrečiai siūlo ir kitą būdą, kaip vertinti krikščionio brandą, pritaikant Gordon'o Allport'o šešis krikščioniškai brandžios asmenybės bruožus: diferencijuotumas (skaidumas), motyvacija, moralinių pasekmių pastovumas, visapusiška apimtis, vientisumas integralumas savo struktūra, heuristiškumas (žr. Paškus, 1990, p. 38-48). G. Allport'o modelis yra ne kas kita kaip ankstesnès jo asmenybės bruožų teorijos pritaikymas religijai. Psichologas H. C. Ruemke savo teorijoje ị tikèjimo vystymąsi žvelgia per Dievo ir žmogaus santykio prizmę. Jo išeities taškas - tikejimas, kaip Dievo pripažinimas ir atsidavimas, skiriant septynias tikejjimo fazes, kurios išryškina ịvairias tiketti trukdančias kliūtis ir iškelia besivystantị, bręstantị ir gėriui pasišvenčiantị tikejjimą (plg. Trimakas, 1998). J. Fowler'is tikejjimo vystymuisi aptarti kaip išeities tašką pasirenka sandoros modelį. Sekdamas jau minètomis E. H. Erikson'o išskirtomis raidos pakopomis, jis žvelgia ị tikejjimą kaip ị pažinimo procesą, lygindamas ji su asmens vystymosi procesu. Jis skiria šešis tikejjimo etapus: intuityvujji projektinị, mitinị literalinị, sintetinị konvencionalųji, individualizuotą reflektyvujji, paradoksalų konsoliduojantiji ir universalizuotaji (plg. Psychology and religion, 1985; Trimakas, 1998). A. Paškus lygiagrečiai pateikia psichologo N. Malony bandymą perkelti G. Allport'o ir religijos tyrinètojų P. Pruyser'io, D. Duncombe, M. Jahoda ịžvalgas dèl krikščioniškos brandos aprašymo. N. Malony prie krikščioniškos religijos apraiškų (kaip žmonès tiki) pridejjo ir esminius jos turinio elementus (sukūrimą, atpirkimą, išteisinimą, atleidimą ir išganymą) bei pareigos dimensiją (kaip tikejjimas reiškiasi kasdieniame 
gyvenime). Autorius subrendusiais krikščionimis laiko tuos, kurie pasižymi krikščioniškaja tapatybe, integralumu - Dievo artumo pajautimu, darnumu ir įkvèpimas, t. y. suvokimu, kad Dievo pagalba, padrąsinimas, globa kasdieniame gyvenime yra prieinami dalykai. N. Malony ir D. O. Nelson'as kaip krikščioniškos brandos kriterijus nurodo Dievo pažinimą, Dievo malonès ir jo nuolatinès meilès prièmimą, atgailos ir atsakomybès supratimą, vadovaujančios ir vedančios Dievo rankos pažinimą, ịsitraukimą ị religinę organizaciją, bendrystès su kitais patyrimą, moralumą ir atvirumą tikèjimui (plg. Paškus, 1990). Šie bruožai leidžia iš dalies apibrèžti krikščioniškajị tapatumą.

Neretai klinikiniai psichologai ir konsultantai (Morgan'as Scott'as Peck'as, Antoine Vergote, Andre Godin'as, David'as Richo, Marius Morin'as, Jean'as Francous Catalan'as ir kt.) krikščionišką dvasinị augimą ir brandą nagrinejja tik psichologiniu aspektu, išryškindami ịvairius dvasinès patirties ir tobulejjimo principus, perspektyvas, ịtampas, pavojus, santykị su psichologija. Minèti autoriai pasitelkdami psichologijos mokslo tyrinèjimus apie žmogų, jo asmenybę ir elgesį imasi aptarti dvasini gyvenimą ir krikščioniškas patirtis psichologijos mokslo kontekste. Remdamiesi prigimtinio proto galiomis, jie ieško psichologinių problemų paaiškinimo ir galimų jų ịveikos būdų. Tuo tarpu krikščioniškoji perspektyva - žvelgti ị dvasini augimą ar jo kliūtis visapusiškai, spręsti žmogaus problemas proto, sielos ir dvasios darnoje - nei atskiriant, nei supriešinant psichologijos tyrinejjimų su dvasine patirtimi, nei juos sumaišant.

\section{Krikščioniškojo dvasinio augimo struktūra ir etapai}

Dvasiškai augant reikšmingai susiję du aspektai: brandos, apimantis pažinimo, moralès, emocinę ir socialinę sritis, bei integracijos, apimantis globalizmo, diferenciacijos ir integracijos aspektus (plg. Becattini, 1989, p. 128; žr. 1 pav.). Ši struktūra leidžia aiškiau ir tiksliau pamatyti dvasinio augimo proceso kontekstą ir aptarti dalyko esmę aiškinantis, iš kur tai kyla ir kur link juda (plg. Клауд, Таунсенд, 2003, p. 25). 


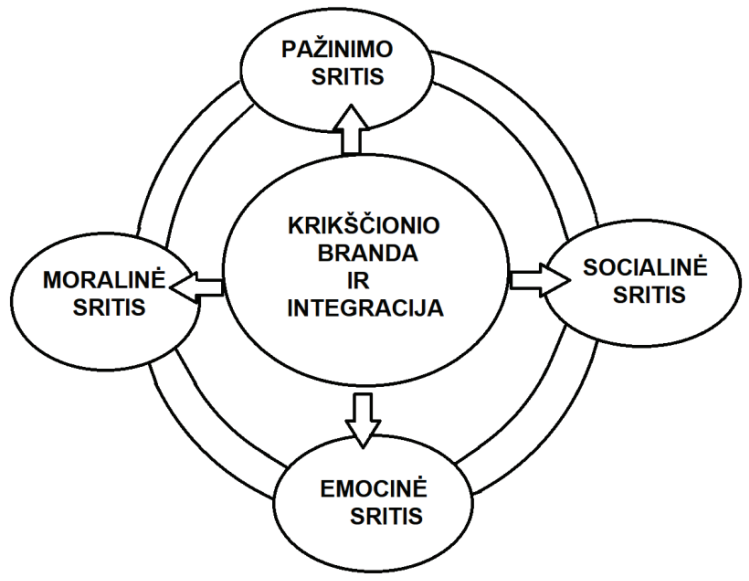

1 pav. Krikščionio brandos ir integracijos aspektai bei gyvenimo sritys (parengta remiantis Becatini, 1989)

Šią sritị tyrinejjusių autorių teigimu, žmogaus augimas iš esmès yra tik dvasinis (plg. Клауд, Таунсенд, 2003, p. 6), remiantis krikščioniškaja antropologija, jis traktuojamas kaip visuma, kurioje protas ir dvasinè siela žmoguje kaip asmenyje yra glaudžiai susiję. Tad ir Dievo pažinimas, emocinis vystymasis, santykių stiprinimas, elgesys suvokiami bei priimami kaip dvasinio augimo dalys. R. Macaulay ir J. Barrs'as (plg. 2000) dvasinio augimo esmę ir prigimtị aptaria kaip tikrojo žmogiškumo atkūrimą, normalios žmogiškos patirties susigrąžinimą - Dievo pirminès kūrinijos ir tobulo Jėzaus pavyzdžio prasme. Vadovaujantis šia perspektyva, žmogaus problemos, jo gyvenimo sunkumai priskirtini ne augimui ar psichologijai, bet dvasinei sričiai, todèl imantis pastarosios sprendimu gaunami ir visi kiti atsakymai. Kita vertus, „dvasinis“ gyvenimas yra neatskiriamas nuo „realaus“, tad emocinès, santykių ir kitos psichologinės problemos gali būti sprendžiamos dvasinio augimo kontekste (plg. Клауд, Таунсенд, 2003). Neretu atveju krikščionys mokslininkai analizuoja individualaus augimo, emocines ar santykių sprendimo problemas ir siekia jas integruoti j krikščioniškaji gyvenimą pasitelkdami dvasines pratybas (maldą, Biblijos skaitymą ir nagrinejimą, atgailą ir pan.), seminarus, etc. Tačiau tokiu 
atveju pastangos dažniausia yra fragmentinès: nukreiptos ị tai, kaip išspręsti vieną ar kitą problemą, o ne sutelkiamos ị visumą.

Dvasinio gyvenimo tyrinètojai (Martin, 2017; Groeschel, 2014), aptardami krikščionių, ypač šventujų Bažnyčios mokytojų (Jėzaus Teresės, Kryžiaus Jono, Kotrynos Sienietės, Bernardo Klerviečio, Pranciško Salezo) dvasinę patirtį, augimui atskleisti pasirenka tradicinį skirstymą - trijų pakopų kelią: nuskaistinimo, apšvietimo ir vienybès. Jame laipsniškai išdėstytas šventumo siekis ir dvasine tikinčiojo augimo raida, jis naudingas ir dvasios vadovams, ir tiems, kurie mąsto ar jau eina šventumo keliu (plg. Szkodon, 2008). B. J. Groeschel'is, kalbėdamas apie dvasinio gyvenimo pradžią, vartoja $p a-$ budimo sąvoką, ịvardydamas tai kaip išgyvenimą, prisilietimą ,prie kažko neapčiuopiamo“, kas kartu yra ir nusiraminimas, ir grèsmès nuojauta. Tai gali būti susipažinimas su kuo nors, ypatingas įvykis, kelionè, asmeninis intymus santykis su Dievu arba netikètas sukrečiantis susitikimas su savimi, kai išryškejja anksčiau nepastebėti realybès aspektai (plg. Groeschel, 2014). Pabudimą dažnai lydi šviesos ir tamsos kaita ir neapleidžia suvokimas, kad nesvarbu, kvietimą priima ar atmeta, jis niekada nebebus toks, koks buvęs.

Iš nuodèmès vergovès ị Dievo vaikų laisvę veda nuskaistinimo kelias (plg. Catechismo degli adulti, 1995, p. 452). Neretai jis vadinamas apsivalymu, kuriam būdingi trys dalykai: moralinè integracija, reikalaujanti atsikratyti sunkios nuodèmès; tikèjimas, kai Evangelijos šviesoje atsiranda poreikis keistis; altruistiškumas ir intuicijos išlaisvinimas. Pirmas žingsnis šiame etape - prisipažinti tikint, kad esi nusidejèlis, pažinti savo nuodèmingumą. Kitas žingsnis - fundamentalus atsivertimas, be kurio neįmanoma kalbèti apie dvasinį augimą (plg. Lk 3, 8; plg. Szkodon, 2008). Jis pasireiškia savo nuodėmių gilumos pažinimu ir Dievo gailestingumo išgyvenimu, nuodèmių išsižadejjimu ir išpažinimu (plg. Catechismo degli adulti, 1995). Krikščionio nuteisinimas, kuri tikintysis dovanai gauna iš Dievo, neatšaukia nuolatinio atsivertimo, kuris kaip dinamiškas procesas tęsiasi visą gyvenimą, žymėdamas tikinčiojo perẻjimą ,,nuo gyvenimo pagal kūną“ prie ,gyvenimo pagal Dvasią“ (plg. Catechismo degli adulti, 1995, p. 452). Tradiciškai apsivalymo samprata apima aktyvų pojūčių, emocijų ir dvasios apsivalymą (plg. Szkodon, 2008). Apaštalas Jonas regejjimo, klausos, lytėjimo, skonio pojūčių 
suvaldymo ir prisirišimo prie laikinujų dalykų nutraukimą vadina „kūno geismo, akių geismo ir pasaulio puikybès" (1 Jn 2, 16) atmetimo procesu dèl didesnio atsivėrimo Šventosios Dvasios veikimui (plg. Szkodon, 2008, p. 212). Šiame etape pabrèžiami dorovès normų prièmimo, reguliarios maldos ir dorybių praktikavimo momentai (plg. Catechismo degli adulti, 1995; Martin, 2017). Čia taip pat ryškus tikejjimu pagrịstas troškimas tobulèti. Apšvietimo (nušvitimo) kelias paženklintas tikèjimo gilinimu ir asmeninès laisvès didinimu vis labiau suvokiant tiesioginio susivienijimo su asmeniškai suvokiamu ir „patiriamu“ Dievu svarbą (plg. Merton, 1997; Groeschel, 2014). R. Martin’as šiame tolesnio dvasinio augimo etape skiria gilesnę maldą, dorybių puoselèjimą, stiprẻjančią meilę artimui, didesnị dorovinị pastovumą, nuoširdesnị atsidavimą Kristaus vedimu, atsitraukimą nuo visko, kas nėra Dievas, ir didejjantị visiško susivienijimo troškimą (plg. Catechismo degli adulti; Martin, 2017). Iš ši etapą lydi išbandymai (,tamsiosios nakties“ patirtis), apvalymas, kartais ir mistiniai reiškiniai. Šie dvasinès kelionès bruožai būdingi ịvairų šventųju religinèms patirtims ir gali padèti nagrinèjant konkrečius dvasinio augimo elementus. P. Scazzero (2007) ši procesą išskaido ị smulkesnius etapus, o „tamsiają naktị““ ịvardija sienos terminu (žr. 2 pav.): tai ištinka kriziniais gyvenimo momentais.

Dvasinio augimo procese krizès, arba „sienos“, gali atlikti dvejopą vaidmenį: regresyvų arba progresyvų. Pirmasis pasireiškia, kai žmogus ,užstringa“ krizès sukeltame skausme, o kartais ir visiškai atsitraukia nuo Dievo, nepajègęs plačiau pažvelgti ị sumaišties kontekstą. Antruoju atveju „siena“ ịveikiama, neretai ši įveika ịvardijama kaip transcendentinè, ji kartu išryškina ir tam padedančias žmogiškąsias savybes: didesnị nusižeminimą, labiau vertinamą šventajji slëpinį, kantresnị Dievo laukimą, mažesnị prisirišimą (plg. Scazzero, 2007). ,Sienos“ ịveika kokybiškai pažangiai keičia asmens dvasini gyvenimą, skatina jo augimą.

Matome, kad dvasinio gyvenimo raidai svarbios ne tik augimo prielaidos, bet ir trukdžiai. Pastaruoju metu aktualizuoti ir nagrinèti įvairūs jų aspektai: didžiosios nuodèmės ir jų įtaką dvasiniam augimui (plg. Bianchi, 2008; Okholm, 2018; Véželienè, 2018; Ševcova ir kiti, 2017); pojūčių svarba dvasiškai augant (plg. Pisarra, 2006); nedorybių ir palaiminimų santykis (plg. Kreeft, 
I ETAPAS

GYVENIMA KEIČIANTIS DIEVO SUVOKIMAS

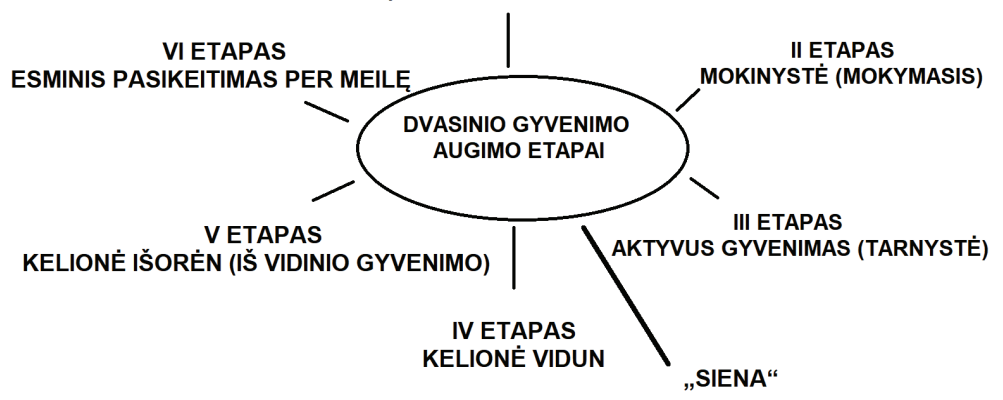

2 pav. Dvasinio gyvenimo augimo etapai (Šaltinis: Scazzero, 2007)

2011) ir kt. Dvasinis augimo raidos skirstymas ne tik leidžia pažinti, kas iš tiesų vyksta tikinčiojo gyvenime, bet ir geriau suvokti eschatologinio pažado prasmę. Etapiškumas paaiškina šventumo kelią ir padeda siekti visapusiško žmogiškojo augimo bei integralaus gyvenimo pagal Dievo planą ir valią.

Verta pažymèti, kad tyrinejjant krikščioniškaji dvasini augimą ir siekiant autentiškesnio bei platesnio požiūrio, neišvengiamai kyla įtampa tarp teologinių ir psichologinių svarstymų: kiek pasiduoti psichologiniams aiškinimams ir tyrimui, o kiek išlaikyti grynai teologinị matmenị. Kai kurie teologai su dvasine patirtimi susijusias psichologijos mokslo pretenzijas ịvardija kaip išdidžias ambicijas užginčyti Dievo Dvasios teisę veikti taip, kaip jai patinka, ir klausia, ,ar tikejjimo gyvenimas tuomet nėra supaprastinamas iki psichologinių mechanizmų funkcionavimo, slaptai veikiančių nesąmoningų kompleksų, infantiliškos ar pažeistos psichikos iliuzinių projekcijų?“ (plg. Catalan, 2003, p. 7). Šioje diskusijoje kiekviena puse teisètai siekia atskleisti dvasinio augimo reiškinį iš savo perspektyvos. Psichologai, kalbėdami apie dvasinị augimą, akcentuoja problemų sprendimą ir aukštesni paciento brandos lygị (plg. Scott Peck, 2012). Teologams yra svarbus atsiverimas Dievo malonei ir vedimui. Kaip minèta, tikintys žmonès patiria ịvairių sunkumų: nerimą, depresiją, baimę, krizes, priklausomybes, netektis, kaltės jausmą, kurie kartais sukelia psichines ar fizines ligas. Pagalbą tikintis žmogus atranda tikèjime, bet kartais jo problemoms spręsti būtina psichologų pagalba. Bū- 
tinybė rinktis tikinčiajam gali sukelti įtampą ar pastatyti ị dviprasmišką situaciją, kurią pripažįsta abi stovyklos - ir teologų, ir psichologų (plg. Nouwen, 2008; Scott Peck, 2012). Ilgą laiką teologija ir psichologija vystèsi atskirai ir kalba apie dvasini bei psichologinį augimą turèjo menkų sąlyčio taškų, nes nebuvo bendro požiūrio (plg. Becattini, 1989, p. 125). İvairūs teoriniai ir praktiniai bandymai integruoti šias sritis ị vieną žmogaus augimo-vystymosi modelį nèra solidūs, bet tiesiog naudingi kaip pagrịstos hipotezės ar paieškos modeliai (plg. Becattini, 1989, p. 125). Pavyzdžiui, ką reiškia krikščioniškame kontekste kai kurių autorių kvietimas dvasiniame kelyje „,susidraugauti su šešèliu“ ar sapnų akcentavimas (plg. Richo, 2011; Morin, 2008), ištraukiant juos iš krikščioniško gyvenimo ir tikejjimo konteksto. Itampos centre atsiduria tikejjimo autonomijos praradimas psichologijos sąskaita. Nors šiandien santykis tarp teologijos ir psichologijos yra dialektiškesnis ir dèmesingesnis, integralaus dvasinio ir psichologinio augimo kūrimo vizija dar neišbaigta. Šios srities autoriai ragina vengti žvelgti ị dvasinị gyvenimą psichologijos akimis, greičiau atvirkščiai - žiūrèti i psichologiją tikejjimo akimis (plg. Crabb, 1977, p. 47), derinant su krikščioniškomis antropologinèmis nuostatomis.

\section{Išvados}

1. Krikščioniškam dvasiniam augimui ịvardyti ir nusakyti vartojamų terminų bei apibrěžčių spektras yra daugiareikšmis ir platus, apimantis ịvairias religinio gyvenimo sritis. Aptarta terminų ir sampratų ịvairovė atskleidžia dvasinio augimo fenomeno daugiadimensiškumą bei leidžia traktuoti ji kaip sudètingą procesą, paremtą Dievo ir žmogaus abipusių santykių įtvirtinimu ir puoselejjimu, vedanti per visišką žmogiškojo asmens išsiskleidimą bei savirealizaciją ị bendrystę su Tèvu, Sūnumi ir Šventaja Dvasia.

2. Krikščioniškasis dvasinis augimas yra dinamiškas procesas, atskleidžiantis krikščioniškojo tikejjimo ir gyvenimo vystymosi bei kaitos tendencijas. Jo šaknys glūdi Šventajame Rašte, Tradicijoje ir Bažnyčios Magisteriume. Dvasiniam augimui būdingi pašaukimo šventèti iššūkiai ir dinamika, kurie gali būti iš dalies pažinti per teologines ir psichologines prieigas. 
3. Dvasinio augimo struktūra apima pažinimo, moralès, emocinę ir socialinę sritis, kurios asmens gyvenime integruoja Dievo pažinimą, elgesị, emocinį vystymąsi bei santykių palaikymą ir stiprinimą. Dvasiniam augimui būdinga pakopinè raida: nuskaistinimo, apšvietimo ir vienybès. Pastarieji etapai atpažịstami šventujų Bažnyčios globėjų bei mokytojų dvasinèse patirtyse, todèl laikytini fundamentaliais. Dvasinio augimo raida gali būti nulemta tiek pozityvių augimo prielaidų, tiek ir trikdžių.

4. Galima teigti, kad esminis krikščioniškojo dvasinio augimo veiksnys - visaapimantis požiūris į žmogaus augimą ir gyvas santykis su Dievu. Tai autentiškos dvasinès brandos ir integracijos prielaida, padedanti išlaikyti pusiausvyrą ir išvengti kraštutinumų, galinčių sukelti neigiamas pasekmes.

\section{Santrumpos}

KBK - Katalikų Bažnyčios katekizmas. 2012. Vilnius: Katalikų pasaulio leidiniai.

LG - Dogminè konstitucija apie Bažnyčią Lumen Gentium. Vatikano II Susirinkimo nutarimai. 2001. Vilnius: Aidai.

GS - Pastoracinè konstitucija apie Bažnyčią šiuolaikiniame pasaulyje Gaudium et Spes. Vatikano II Susirinkimo nutarimai. 2001. Vilnius: Aidai.

AA - Dekretas dèl pasauliečiu apaštalavimo Apostolicam Actuositatem. Vatikano II Susirinkimo nutarimai. 2001. Vilnius: Aidai.

GE - Šventasis Tẻvas Pranciškus. 2018. Apaštalinis paraginimas Gaudete et Exultate. Apie pašaukimą ị šventumą šiuolaikiniame pasaulyje. Vilnius: Lietuvos Vyskupų Konferencija.

\section{Literatūra}

Becattini, C. (1989). Crescita psicologica e crescita spirituale. Teresianum, Vol. 40, No. 1, p. 125-148. Prieiga internete: https://dialnet.unirioja.es/descargaarticulo/5363843.pdf [žiūrèta 2019-02-18].

Bianchi, E. (2008). Nemoku myleti tad valgau. Prieiga internete: <http://www.bernardinai.lt/straipsnis/2008-02-06-enzo-bianchi-nemoku-myleti-tad-valgau/8726> [žiūreta 2019-02-21].

Catalan, J. F. (2003). Dvasine patirtis ir psichologija. Vilnius: Dialogo kultūros institutas. 
Catechismo degli adulti. La verita vi fara liberi. (1995). Vaticano: Libreria Editrice Vaticano.

Crabb, L. J. (1977). Effective biblical counselling. Michigan: Zondervan Publishing House.

Dajczer, T. (2010). Tikejjimo ǰžvalgos. Vilnius: Katalikų pasaulio leidiniai.

Dogminè konstitucija apie Bažnyčią Lumen Gentium. (2001). Vatikano II Susirinkimo nutarimai. Vilnius: Aidai.

Erickson, E. H. (2004). Vaikystè ir visuomenè. Vilnius: Katalikų pasaulio leidiniai.

Frielingsdorf, K. (2003). Demoniški Dievo j̣vaizdžiai. Vilnius: Katalikų pasaulis.

Giussani, L. (2007). Kodèl Bažnyčia? Vilnius: Katalikų pasaulio leidiniai.

Groeschel, B. J. (2014). Dvasingumo keliai. Vilnius: Katalikų pasaulio leidiniai.

Hart, T. N. (2001). Klausymosi menas. Kaunas: Kauno reklamos centras.

Katalikų Bažnyčios katekizmas. (2012). Vilnius: Katalikų pasaulio leidiniai.

Kavaliauskas, Č. (1992). Trumpas teologijos žodynas. Vilnius: Lumen.

Kreeft P. (2011). Grįžti prie dorybių. Vilnius: Katalikų pasaulio leidiniai.

Macaulay, R., Barrs, J. (2000). Būti žmogumi. Šiauliai: Nova vita.

Martin, R. (2017). Troškimų išsipildymas. Vilnius: Katalikų pasaulio leidiniai.

Merton, T. (1997). Gyvenimas ir šventumas. Vilnius: Katalikų pasaulis.

Morin M. (2008). Iškęsti ir tobuleti. Vilnius: Katalikų pasaulio leidiniai.

Nouwen, H. J. M. (2008). Siekimas. Vilnius: Katalikų pasaulio leidiniai.

Nuovo dizionario di teologia. (1988). Milano: Edizioni paoline.

Okholm D. (2018). Pavojingos aistros, mirtinos nuodemès. Vilnius: Katalikų pasaulio leidiniai.

Pastoracinė konstitucija apie Bažnyčią šiuolaikiniame pasaulyje Gaudium et Spes. (2001). Vatikano II Susirinkimo nutarimai. Vilnius: Aidai.

Paškus, A. (1990). Asmenybe ir religija. Chicago: Ateitis.

Pisarra, P. (2006). Pojūčiai ir dvasingumas. Prieiga internete: <http://www.bernardinai.lt/straipsnis/2005-12-18-piero-pisarra-pojuciai-ir-dvasingumas-ivadasi/8966> [žiūrèta 2019-03-02].

Psychology and religijon. (1985). New York: Paulist Press.

Richo, D. (2011). Būti suaugusiems. Vilnius: Katalikų pasaulio leidiniai.

Rolheiser, R. (2017). Dvasingumo paieškos. Vilnius: Katalikų pasaulio leidiniai.

Rupnik, M. I. (1997). Nesudegančio erškètyno liepsnoje. Vilnius: Aidai.

Scazzero, P. (2010). Emociškai brandus dvasingumas. Vilnius: Misionieriškas labdaros fondas „Šviesa Rytuose“.

Scott Peck, M. (2012). Nepramintuoju taku. Vilnius: Vaga.

Stott, J. (2004). Šiuolaikinis krikščionis. Vilnius: Tikejjimo žodis.

Szkodon, J. (2008). Kas yra kasdienio gyvenimo dvasingumas. Vilnius: Katalikų pasaulio leidiniai. 
Ševcova, L. ir kt. (2017). Aistros ịveika. Kaunas: Vox altera.

Šventasis Raštas. Senasis ir Naujasis Testamentas. (1998). Vilnius: Lietuvos Vyskupu Konferencija.

Šventasis Tèvas Pranciškus. (2018). Apaštalinis paraginimas Gaudete et Exultate. Apie pašaukimą į šventumą šiuolaikiniame pasaulyje. Vilnius: Lietuvos Vyskupu Konferencija.

Trimakas, K. A. (1998). Tikint bręsti. Kaunas: Lietuvos katechetikos centro leidykla.

Vanier, J. (2006). Kiekvienas žmogus - šventa istorija. Vilnius: Katalikų pasaulio leidiniai.

Vèželienè, L. (2018). Septynios didžiosios nuodèmès psichologo kabinete. Vilnius: Tyto alba.

Vorgrimler, H. (2003). Naujasis teologijos žodynas. Kaunas: Katalikų interneto tarnyba.

Альбисетти, В. (2001). Путешествие жизни. Москва: Paoline.

Клауд, Г., Таунсенд, Дж. (2003). Как люди растут. Москва: Триада.

Клауд, Г., Таунсенд, Дж. (2005). 12 „христианских“ верований, которые могут свести с ума. Москва: Триада.

\section{THE CONCEPT AND FEATURES OF THE DEVELOPMENT OF CHRISTIAN SPIRITUAL GROWTH}

\section{Albinas Šiaudvytis, Vaineta Juškienė}

Summary

The need to grow is the calling of every person's life. Spiritual growth is based on the concern of God himself, when he created mankind "in his own image and likeness" (Genesis 1: 27), wished him as an interlocutor and friend, and allowed him to become a suitable partner in dialogue. Both the people of the nation of the Old Covenant and the members of the Church were and are invited to grow and become holy - to drive their lives into authentic fellowship with God. Jesus not only urged his followers to become holy, but also showed an example of spiritual growth in his life. With the help of the Holy Spirit, God constantly encourages the desire of people to improve and 
helps to implement it with various graces and gifts. But Christians, who are following Jesus, often experience tensions and difficulties when the growth of their faith is faced with the reality of life. These challenges reflect the continued relevance of the analysed topic and encourage the search for new insights. In this context, it is important to discuss the Christian vocation to grow, to become acquainted with its theories, structure and stages, and to be aware of the possible tensions between theology and psychology in exploring this phenomenon. It is equally important to reveal the basic Christian prerequisites that lead to authentic spiritual growth. Considering these realities, the purpose of this article is to discuss the concept and prerequisites of Christian spiritual growth in the context of current affairs. Methods of research are literary analysis, systematization and interpretation. The study is based on humanistic attitudes that highlight the spiritual origin of a person and consider it a fundamental innate foundation of human development. According to this approach, a person is constantly in the process of becoming. Christian spiritual growth is an integral part of the aforementioned becoming.

The course of the study revealed some features of the concept and development of Christian spiritual growth. The range of terms and definitions used to denote and define Christian spiritual growth is multi-dimensional and broad, encompassing various areas of religious life. The diversity of the discussed terms and concepts reveals the multi-dimensional aspect of the phenomenon of spiritual growth and allows to view it as a complex process based on the establishment and fostering of reciprocal relations between God and man, and leading through the ultimate unfolding and self-fulfilment of a person towards the communion with the Father, Son, and Holy Spirit.

Christian spiritual growth is a dynamic process that reveals trends in the development and change of Christian faith and life. Its roots lie in the Holy Scripture, Tradition and the Magisterium of the Catholic Church. Spiritual growth is characterized by challenges and dynamics of vocation to holiness, which can be partially acknowledged through theological and psychological approaches.

The structure of spiritual growth includes cognitive, moral, emotional and social areas that integrate God's cognition, behaviour, emotional develo- 
pment and the maintenance and strengthening of relationships in a person's life. Spiritual growth is described by gradual development: purification, revelation and unity. The latter stages are evident in the spiritual experiences of the holy guardians and teachers of the Church and are therefore considered fundamental. Spiritual development can be conditioned by both positive prerequisites and obstacles for growth.

It can be argued that the fundamental factor of Christian spiritual development is a holistic approach to human growth and a live relationship with God. It is a prerequisite for genuine spiritual maturity and integration, helping to maintain balance and avoid extremes that can lead to negative consequences. 